\title{
NGHIÊN CỨU HOAT HÓA HẠT TẾ BÀO NẤM MEN CỐ ĐỊNH SAU THỜI GIAN XÚC TÁC CHO QUÁ TRİNH LÊN MEN RƯợU
}

\author{
Nguyễn Thị Hương ${ }^{1, ~ *}$, Hoàng Đình Hòa ${ }^{1}$, Đặng Hồng Ánh ${ }^{2}$ \\ ${ }^{1}$ Truoòng Đại học Bách khoa Hà Nội, số 1, Đại Cồ Việt, Quận HBT, Hà Nội \\ ${ }^{2}$ Viện Công nghiệp Thưcc phẩm, số 301 Nguyễn Trãi, Thanh Xuân, Hà Nội \\ *Email: huong.nguyenthi1@ @ust.edu.vn
}

Đến Toà soạn: 10/6/2012; Chấp nhận đăng: 29/8/2013

\section{TÓM TÁT}

Sau một thời gian lên men rượu, nấm men $S$. cerevisiae cố định trên chất mang Ca-Alginate sẽ bị suy giảm dần đặc tính công nghệ. Để phục hồi về khối lượng nấm men cũng như chất lượng của chúng, trong công trình này nhóm tác giả đã đưa ra giải pháp công nghệ như sau :

- Tiến hành rửa hạt sau 40 ngày lên men liên tục.

- Dung dịch rửa giá thể là $\mathrm{NaHCO}_{3} 0,5 \%$.

- Nuôi lắc 200 vòng/phút ở $30^{\circ} \mathrm{C}$ thời gian là 24 giờ.

- Bổ sung urê nồng độ $0,05 \% ; \mathrm{KH}_{2} \mathrm{PO}_{4} 0,05 \%$.

- Nấm men sau khi hoạt hóa có thể lên men tạo độ cồn 10,7\%.

Từ khóa: cồn, lên men liên tục, tế bào cố định, rỉ đường.

\section{MỞ ĐẦU}

Sau một thời gian sử dụng, nấm men được cố định trong gel Ca-alginate sẽ mất dần khả năng lên men do số lượng tế bào nấm men sống giảm, kết quả là độ cồn trong dịch lên men thấp. Nhằm khắc phục tồn tại này, thì cần hoạt hoá hạt gel nhằm tăng số lượng nấm men trong gel cũng như giải pháp bồ sung thêm một số cơ chất hoạt để tăng số lượng, chất lượng nấm men bên trong hạt được nghiên cứu.

Vi sinh vật nói chung cần sử dụng nguồn dinh dưỡng thích hợp cho sinh trưởng và phát triển. Nhu cầu về dinh dưỡng của từng loại nấm men khác nhau là khác nhau.

\subsection{Nhu cầu về cacbon}

Glucoza được tất cả các loài nấm men sử dụng, ngoài ra các đường đôi như maltoza, saccaroza,... các axit hữu cơ, axit béo, hydrocacbon từ dầu mỏ và khí đốt cũng là nguồn dinh dưỡng cacbon của một số nấm men [1]. 


\subsection{Nhu cầu về nito}

Đa số nấm men không đồng hóa được nitrat. Nguồn nitơ vô cơ được nấm men sử dụng tốt là các muối amoni của axit vô cơ cũng như hữu cơ.

\subsection{Nhu cầu muối khoáng}

Photpho tham gia vào các thành phần quan trọng của tế bào như các nucleotit, axit nucleic, polyphosphat... Các hợp chất photpho đóng vai trò trong các biến đổi hóa sinh khác nhau, đặc biệt là trong trao đổi hydratcacbon và vận chuyển năng lượng. Magie có tác dụng hoạt hóa nhiều photphatlaza, enolaza. Magie làm tăng nhanh nhu cầu về nitơ của nấm men. Ảnh hưởng của magie mạnh hơn khi nồng độ glucoza trong môi trường thấp. Lưu huỳnh là thành phần của một số axit amin trong phân tử protein và là nhóm phụ của một số enzim CoA [1].

\subsection{Một số yếu tố ảnh hưởng tới quá trình sinh trưởng của nấm men}

\subsubsection{Oxy}

Hầu hết nấm men thuộc chi Saccharomyces là sinh vật yếm khí tùy tiện. Trong môi trường có đủ oxy, nấm men sẽ tiến hành hô hấp, sinh trưởng để tăng số lượng tế bào. Khi môi trường thiếu oxy, chúng tiến hành lên men đường thành rượu.

\subsubsection{Nhiệt độ}

Nhiệt độ tối ưu cho sinh trưởng của nấm men là $28-30{ }^{\circ} \mathrm{C}$ nhưng nhiệt độ lên men lại không phải là nhiệt độ này. Hoạt tính hô hấp của nấm men bị giảm khi nhiệt độ xuống thấp: cường độ hô hấp ở $5^{\circ} \mathrm{C}$ bằng $1 / 5$ so với ở $30^{\circ} \mathrm{C}$. Nấm men hoản toàn bị ức chế ở $2-5^{\circ} \mathrm{C}$.

\subsection{3. $\mathrm{pH}$}

pH môi trường có ảnh hưởng tới quá trình trao đổi chất của tế bào nấm men là do ảnh hưởng tói hoạt động của hệ enzim nội bào. Mặt khác, khi $\mathrm{pH}$ thay đổi làm điện tích màng tế bào thay đổi, dẫn tới thay đổi tính thẩm thấu của màng này. Men rượu, men bia thuộc giống này thì $\mathrm{pH}$ ban đầu thích hợp cho lên men là 5,5 , còn với men rượu vang nấm men có thể lên men ở $\mathrm{pH}$ $2,8-3,8$.

\section{NGUYÊN LIỆU VÀ PHƯƠNG PHÁP}

\subsection{Nguyên liệu}

\subsubsection{Giống vi sinh vật}

Nấm men Saccharomyces cerevisiae 7028 từ bộ sưu tập giống Vi sinh vật, Viện Công nghệ thực phẩm được cố định trong gel Canxi alginat đã lên men 40, 45, 50 ngày.

\subsubsection{Rỉ đường}

Rỉ đường của nhà máy đường Nông Cống, Thanh Hóa đã được lựa chọn.

\subsubsection{Môi truờng hoạt hóa hạt và lên men}


- Môi trường hoạt hóa hạt: glucose 100 g/l; cao nấm men 5 g/l; $\mathrm{KH}_{2} \mathrm{PO}_{4} 1$ g/l; $\mathrm{MgSO}_{4}$ 1g/l, $\mathrm{pH} 5,0$.

- Môi trường lên men: Rỉ đường đã xử lí được điều chỉnh về nồng độ thích hợp, bổ sung dinh dưỡng $\left(\mathrm{NH}_{4}\right)_{2} \mathrm{SO}_{4} 3 \mathrm{~g} / \mathrm{l}, \mathrm{KH}_{2} \mathrm{PO}_{4} 1 \mathrm{~g} / \mathrm{l}, \mathrm{MgSO}_{4} 0,5 \mathrm{~g} / \mathrm{l}, \mathrm{pH}$ 5,0. Hấp thanh trùng $121{ }^{\circ} \mathrm{C} / 30$ phút.

\subsection{Phương pháp nghiên cứu $[4,6]$}

\subsubsection{Phương pháp hoạt hóa hạt tế bào nấm men cố định}

Hạt tế bào nấm men cố định trong gel Canxi alginat đã lên men 40, 45, 50 ngày lên men được ngâm vào môi trường hoạt hóa trong 24 giờ, sau đó cho lên men để kiểm tra khả năng tạo cồn.

\subsubsection{Phương pháp sơ tuyển khả năng lên men của hạt TB nấm men cố định}

Cho một cách vô trùng $2,5 \mathrm{~g}$ hạt $\mathrm{TB}$ nấm men cố định vào $7,5 \mathrm{ml}$ dịch rỉ đường đã xử lí vào bình Engol. Điều chỉnh cột dịch rỉ đường về vạch $0 \mathrm{ml}$ của bình. Lên men ở $30^{\circ} \mathrm{C}$, theo dõi thời gian hạt $\mathrm{TB}$ nấm men cố định lên men sinh $\mathrm{CO}_{2}$ đẩy hết $5 \mathrm{ml}$ cột môi trường.

\subsubsection{Xác định số lượng tế bào nấm men được cố định trong hạt gel canxi alginat}

Làm tan gel canxi alginat bằng dung dịch $\mathrm{Na}_{2} \mathrm{CO}_{3} 0,05 \mathrm{M}$ trong axit citric $0,02 \mathrm{M}$ trong 2 giờ. Sau đó đếm lượng tế bào nấm men trong buồng đếm Thomas (sử dụng thuốc nhuộm xanh methylen để đếm số lượng tế bào sống).

2.2.4. Xác định số lương vi khuẩn hiếu khí có trong dịch lên men:

Vi khuẩn hiếu khí có trong dịch lên men được kiểm tra trên môi trường Plate Count Agar.

\subsubsection{Xác định lượng đường khử}

Đường khử được xác định theo phương pháp Nelson - Somogi

\subsubsection{Xác định lượng cồn tạo thành}

Cồn được xác định bằng bộ cất cồn phòng thí nghiệm Salleron Dujardin (Pháp).

\subsubsection{Xác định độ chua của dấm chín}

Dịch rỉ đường sau lên men được xác định $\mathrm{pH}$ bằng máy đo $\mathrm{pH}$ điện tử.

\section{KẾT QUẢ VÀ THẢO LUẬN}

\subsection{Xác định thời điểm cần hoạt hóa để kéo dài hoạt lực của các tế bào cố định}

Hạt tế bào nấm men cố định sau 40, 45, 50 ngày lên men được ngâm trong môi trường hoạt hóa 24 giờ. Sau đó, hạt được chuyển vào môi trường lên men để kiểm tra khả năng lên men tạo cồn. Kết quả được trình bày ở bảng 1 .

Bảng 1 cho thấy, hạt tế bào cố định được hoạt hóa sau 40 ngày lên men cho kết quả lên men tốt nhất, khi kéo dài thời điểm hoạt hóa sau 40 ngày thì dù hoạt tính của hạt có được cải thiện so với trước khi hoạt hóa nhưng vẫn thấp hơn so với khi được hoạt hóa sớm ở thời điểm 40 
ngày, độ cồn đạt được 10,7 (\% v/v), lượng tế bào sống và nảy chồi cũng cao hơn các mẫu khác. Thí nghiệm này cũng phù hợp với kết quả thí nghiệm trước khi đánh giá hiệu quả lên men của tế bào nấm men cố định theo thời gian.

Bảng 1. Ảnh hưởng của thời điểm hoạt hóa đến khả năng lên men của hạt tế bào nấm men cố định.

\begin{tabular}{|c|c|c|c|c|c|c|c|}
\hline $\begin{array}{c}\text { Thời điểm } \\
\text { hoạt hóa }\end{array}$ & \multirow{2}{*}{$\begin{array}{c}\text { Độ cồn } \\
(\% \mathrm{v} / \mathrm{v})\end{array}$} & $\begin{array}{c}\mathrm{CO}_{2}(\mathrm{~g} / 30 \\
\mathrm{ml})\end{array}$ & $\begin{array}{c}\text { Đường } \\
\text { sót }(\mathrm{g} / \mathrm{l})\end{array}$ & $\mathrm{pH}$ & \multicolumn{3}{|c|}{$\begin{array}{c}\text { Mật độ tế bào nấm men trong hạt tế bào } \\
\text { cố định }\left(\mathrm{CFU} \times 10^{8} / \mathrm{g}\right)\end{array}$} \\
\cline { 6 - 9 } & & Tổng số & TB sống & TB nảy chồi \\
\hline $\begin{array}{c}\text { Sau 40 ngày lên } \\
\text { men }\end{array}$ & 10,7 & 2,85 & 21,56 & 4,3 & 6,95 & 5,01 & 1,32 \\
\hline $\begin{array}{c}\text { Sau 45 ngày lên } \\
\text { men }\end{array}$ & 9,2 & 2,55 & 23,85 & 4,2 & 6,10 & 4,09 & 1,27 \\
\hline $\begin{array}{c}\text { Sau 50 ngày lên } \\
\text { men }\end{array}$ & 8,6 & 2,11 & 23,92 & 4,2 & 5,75 & 3,79 & 1,20 \\
\hline
\end{tabular}

Sau 40 ngày lên men ổn định, hạt tế bào nấm men cố định cần được hoạt hóa để kéo dài thời gian lên men, đây là thời điểm hoạt lực của hạt tế bào cố định bắt đầu bị ảnh hưởng rõ rệt, nếu việc hoạt hóa tiến hành chậm hơn thì hiệu quả hoạt hóa là rất thấp.

\section{2. Ảnh hưởng của dung dịch rửa hạt tế bào nấm men cố định đến quá trình lên men}

Để nghiên cứu ảnh hưởng của dung dịch rửa hạt tế bào nấm men cố định đến quá trình lên men, tiến hành loại bỏ cặn rỉ đường, các chất phi đường, một phần vi sinh vật tạp nhiễm... bám trên bề mặt hạt tế bào nấm men cố định sau thời gian sử dụng 40 ngày bằng các dung dịch rửa hạt như $\mathrm{NaHCO}_{3}$, EDTA.

Kết quả sau lên men được trình bày trong bảng 2 và hình 1 .

Bảng 2. Ảnh hưởng của dung dịch rửa hạt đến quá trình lên men trong hệ thống lên men liên tục.

\begin{tabular}{|c|c|c|c|c|c|c|c|c|}
\hline \multirow{2}{*}{ Mẫu } & \multirow{2}{*}{$\begin{array}{l}\text { Độ cồn } \\
(\% \mathrm{v} / \mathrm{v})\end{array}$} & \multirow{2}{*}{$\begin{array}{l}\mathrm{CO}_{2} \\
(\mathrm{~g} / 30 \\
\mathrm{ml})\end{array}$} & \multirow{2}{*}{$\begin{array}{l}\text { Đường } \\
\text { sót } \\
(\mathrm{g} / \mathrm{l})\end{array}$} & \multirow{2}{*}{$\mathrm{pH}$} & \multicolumn{2}{|c|}{$\begin{array}{l}\text { Nấm men trong hạt } \\
\text { TB cố định } \\
\left(\mathrm{CFU} \times 10^{8} / \mathrm{g}\right)\end{array}$} & \multirow{2}{*}{$\begin{array}{c}\text { TB tự do } \\
\text { trong dịch } \\
\left(\mathrm{CFU} \times 10^{6} / \mathrm{g}\right)\end{array}$} & \multirow{2}{*}{$\begin{array}{c}\text { Vi sinh vật } \\
\text { hiếu khí } \\
\left(\mathrm{CFU} \times 10^{7}\right. \\
\mathrm{ml})\end{array}$} \\
\hline & & & & & TB sống & $\begin{array}{c}\text { TB nảy } \\
\text { chồi }\end{array}$ & & \\
\hline Đối chứng & 6,6 & 1,62 & 44,81 & 4,5 & 2,65 & 0,62 & 0,95 & 9,85 \\
\hline Nước cất & 6,7 & 1,82 & 43,40 & 4,5 & 2,54 & 0,98 & 0,54 & 8,91 \\
\hline $\mathrm{NaCl} 0,9 \%$ & 6,9 & 1,89 & 43,27 & 4,5 & 3,02 & 1,05 & 0,65 & 8,52 \\
\hline $\mathrm{NaHCO}_{3} 0,5 \%$ & 7,2 & 1,90 & 40,05 & 4,3 & 3,10 & 1,20 & 0,41 & 7,53 \\
\hline $\mathrm{NaHCO}_{3} 0,7 \%$ & 7,1 & 1,93 & 42,55 & 4,5 & 2,95 & 1,24 & 0,42 & 7,59 \\
\hline $\mathrm{NaHCO}_{3} 1 \%$ & 7,1 & 1,82 & 42,69 & 4,4 & 3,07 & 1,18 & 0,41 & 6,51 \\
\hline EDTA 5 ppm & 7,1 & 1,84 & 42,01 & 4,4 & 3,4 & 1,03 & 5,51 & 5,50 \\
\hline EDTA 7 ppm & 7,0 & 1,81 & 42,25 & 4,4 & 3,12 & 1,04 & 5,82 & 6,30 \\
\hline EDTA $10 \mathrm{ppm}$ & 7,2 & 1,91 & 40,01 & 4,3 & 2,98 & 1,08 & 8,03 & 7,52 \\
\hline
\end{tabular}

Chú ý: Đối chứng là hạt không rửa. 
Kết quả ở bảng 2 và hình 1 cho thấy, độ cồn sau lên men của tất cả các mẫu dùng dung dịch rửa hạt đều cao hơn so với mẫu đối chứng (không rửa hạt). Nguyên nhân là do các cặn bẩn của rỉ đường bám trên bề mặt hạt đã được rửa trôi để tăng khả năng tiếp xúc của hạt với dịch rỉ đường, nhờ đó nấm men sinh trưởng và lên men tốt hơn, kết quả là hàm lượng cồn trong dịch lên men cao hơn. Bên cạnh đó, lượng vi sinh vật hiếu khí trong các mẫu được rửa cũng giảm hơn so với mẫu đối chứng không rửa, do dung dịch rửa hạt ngoài việc loại bỏ các cặn bẩn môi trường còn có tác dụng rửa trôi 1 phần các vi sinh vật nhiễm tạp bám trên bề mặt hạt. Vậy việc sử dụng dung dịch rửa hạt là có tác dụng tốt đối với quá trình lên men cồn.

Trong các dung dịch rửa hạt, dung dịch $\mathrm{NaHCO}_{3} 0,5 \%$ cho độ cồn thu được cao nhất (đạt $7,2 \% \mathrm{v} / \mathrm{v})$, lượng đường sót thấp nhất, sinh trưởng của nấm men tốt, lượng tế bào thoát ra ngoài môi trường rất thấp. Ngoài ra mẫu sử dụng dung dịch rửa EDTA $10 \mathrm{ppm}$ tuy độ cồn đạt 7,2 \% v/v nhưng do EDTA làm lỏng lẻo cấu trúc hạt canxi alginat nên lượng nấm men bị thoát ra môi trường nhiều hơn 19 lần so với mẫu sử dụng $\mathrm{NaHCO}_{3} 0,5 \%$.

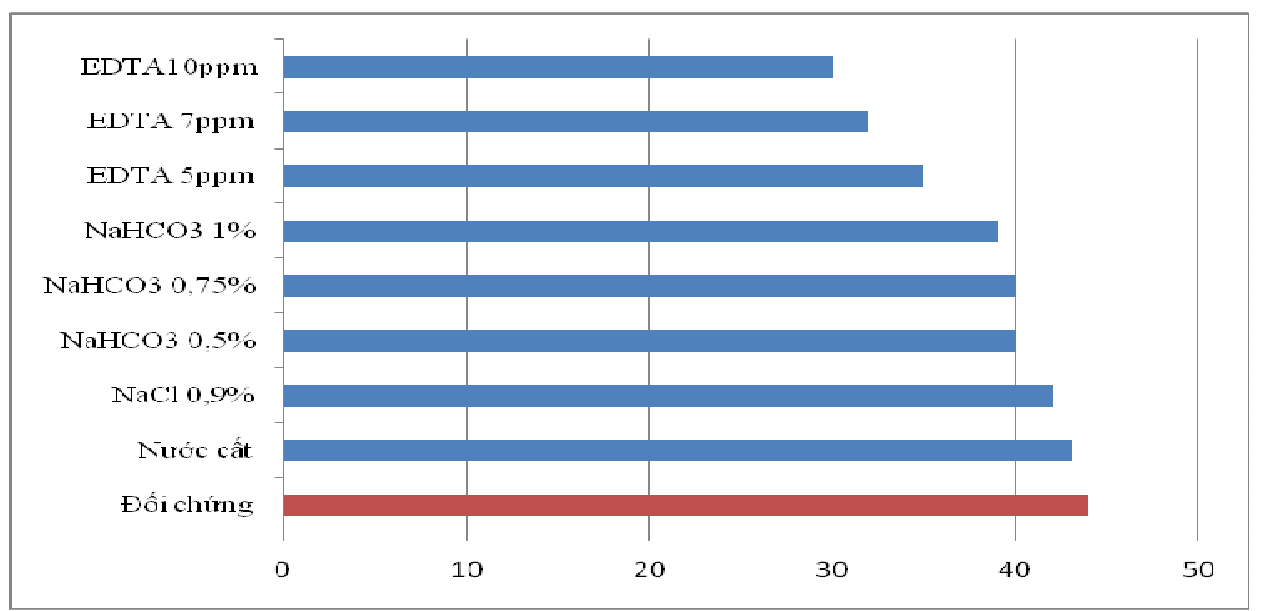

Chú ý: Đối chứng là hạt không rửa.

Hình 1. Thời gian sinh $\mathrm{CO}_{2}$ đẩy hết $5 \mathrm{ml}$ cột dịch trong bình engol sau khi dùng dung dịch rửa hạt $\mathrm{TB}$ nấm men cố định.

Vậy dung dịch $\mathrm{NaHCO}_{3} 0,5 \%$ được lựa chọn làm dung dịch rửa hạt sau thời gian lên men 40 ngày trước khi đưa vào môi trường hoạt hóa.

\subsection{Nghiên cứu ảnh hưởng của oxy hòa tan để nâng cao khả năng sống và duy trì hoạt tính lên men của các tế bào cố định}

Để nghiên cứu ảnh hưởng của oxy tới quá trình hoạt hóa tế bào để từ đó đưa ra phương pháp thực hiện việc hoạt hóa hạt tế bào cố định để tăng số lượng, chất lượng nấm men bên trong hạt thì hai phương pháp nuôi tĩnh và nuôi lắc 200 vòng/ phút ở $30^{\circ} \mathrm{C}$ trong 24 giờ. Kết quả ghi lại trong bảng 3 .

Kết quả bảng 3 cho thấy sự khác biệt rõ ràng giữa mẫu hoạt hóa và không hoạt hóa, giữa hoạt hóa có lắc và tĩnh. Hàm lượng cồn trong dịch lên men bằng hạt đã hoạt hóa cao hơn hẳn mẩu đối chứng (mẫu nuôi cấy lắc hàm lượng cồn $10,9 \% \mathrm{v} / \mathrm{v}$; mẫu nuôi tĩnh hàm lượng cồn đạt $10,1 \% \mathrm{v} / \mathrm{v}$; trong khi mẫu đối chứng không hoạt hóa hàm lượng cồn chỉ đạt 8,4\% v/v). Tống số tế bào nấm men, số lượng tế bào sống và số lượng tế bào nảy chồi tăng lên rất nhiều, đặc biệt là 
mẫu nuôi cấy lắc. Lý giải nguyên nhân do nấm men sinh trưởng trong điều kiện lắc làm tăng hàm lượng oxy hòa tan trong dịch, đồng thời cũng làm tăng sự tiếp xúc của hạt với môi trường dinh dưỡng, kết quả là sinh trưởng của nấm men bên trong hạt tốt hơn vì vậy hàm lượng cồn trong dịch lên men sau khi hạt được hoạt hóa cũng cao hơn. Như vậy oxy hòa tan đóng vai trò tích cực trong việc nâng cao hoạt lực của hạt tế bào nấm men cố định trong quá trình hoạt hóa. Do vậy, phương pháp hoạt hóa hạt đã qua sử dụng bằng phương pháp nuôi cấy lắc 200 vòng / phút; $30^{\circ} \mathrm{C}$ trong 24 giờ được lựa chọn.

Bảng 3. Ảnh hưởng của phương pháp hoạt hóa tới quá trình lên men của hạt tế bào nấm men cố định.

\begin{tabular}{|c|c|c|c|c|c|c|c|}
\hline \multirow{2}{*}{ Mẫu } & \multirow{2}{*}{$\begin{array}{c}\text { Đồ } \\
\text { cồn } \\
(\% \mathbf{q} / \mathbf{v})\end{array}$} & \multirow{2}{*}{$\begin{array}{c}\mathrm{CO}_{2} \\
(\mathrm{~g} / \mathbf{3 0 m l})\end{array}$} & \multirow{2}{*}{$\begin{array}{l}\text { Đường } \\
\text { sót } \\
\text { (g/l) }\end{array}$} & \multirow[b]{2}{*}{ pH } & \multicolumn{2}{|c|}{$\begin{array}{l}\text { Nấm men trong } \\
\text { hạt tế bào cố định } \\
\left(\text { CFU× } 10^{8} / \mathrm{g}\right)\end{array}$} & \multirow{2}{*}{$\begin{array}{c}\text { Vi sinh } \\
\text { vật hiếu } \\
\text { khí } \\
\text { (CFU×10 } \\
\text { /ml) }\end{array}$} \\
\hline & & & & & $\begin{array}{c}\text { TB } \\
\text { sống }\end{array}$ & $\begin{array}{l}\text { TB } \\
\text { nảy } \\
\text { chồi }\end{array}$ & \\
\hline Đối chứng & 8,4 & 2,63 & 29,89 & 4,3 & 4,33 & 1,15 & 2,53 \\
\hline Hoạt hóa lắc & 10,9 & 3,45 & 19,57 & 3,9 & 5,33 & 2,80 & 19 \\
\hline Hoạt hóa tĩnh & 10,1 & 3,06 & 21,54 & 3,9 & 5,17 & 1,97 & 15 \\
\hline
\end{tabular}

Chú ý: Đối chứng là hạt không hoạt hóa.

\section{4. Ảnh hưởng của nguồn nitơ đến quá trình hoạt hóa hạt tế bào nấm men cố định}

Để lựa chọn ra nguồn nitơ thích hợp cho sự sinh trưởng của tế bào nấm men cố định, tiến hành hoạt hóa hạt tế bào nấm men cố định trên môi trường glucose $10 \%$ với các nguồn nitơ khác nhau (nguồn vô cơ và hữu cơ). Đánh giá quá trình sinh trưởng và hiệu suất lên men của tế bào nấm men sau khi hoạt hóa, kết quả thể hiện tại bảng 4 .

Bảng 4. Ảnh hưởng của nguồn nitơ trong dịch hoạt hóa đến khả năng lên men của hạt tế bào nấm men cố định.

\begin{tabular}{|c|c|c|c|c|c|c|c|c|}
\hline \multirow[t]{2}{*}{ Nguồn nitơ } & \multirow{2}{*}{$\begin{array}{l}\text { Độ cồn } \\
(\% \mathrm{v} / \mathrm{v})\end{array}$} & \multirow{2}{*}{$\begin{array}{c}\mathrm{CO}_{2} \\
(\mathrm{~g} / 30 \mathrm{ml})\end{array}$} & \multirow{2}{*}{$\begin{array}{l}\text { Đường } \\
\text { sót }(\mathrm{g} / \mathrm{l})\end{array}$} & \multirow[t]{2}{*}{$\mathrm{pH}$} & \multicolumn{3}{|c|}{$\begin{array}{c}\text { Nấm men trong hạt tế } \\
\text { bào cố định } \\
\left(\mathrm{CFU} \times 10^{8} / \mathrm{g}\right) \\
\end{array}$} & \multirow{2}{*}{$\begin{array}{c}\text { Vi sinh vật hiếu } \\
\text { khí } \\
\left(\mathrm{CFU} \times 10^{5} / \mathrm{ml}\right)\end{array}$} \\
\hline & & & & & $\begin{array}{c}\text { Tổng } \\
\text { số }\end{array}$ & $\begin{array}{c}\mathrm{TB} \\
\text { sống }\end{array}$ & $\begin{array}{c}\text { TB nảy } \\
\text { chồi }\end{array}$ & \\
\hline $\begin{array}{l}\text { Ni tơ vô cơ } \\
\text { (urê) }\end{array}$ & 10,7 & 2,85 & 22,91 & 4,2 & 6,52 & 5,11 & 1,42 & 1,92 \\
\hline $\begin{array}{l}\text { Ni tơ hữu cơ } \\
\text { (cao nấm men) }\end{array}$ & 10,6 & 2,75 & 22,93 & 4,2 & 6,52 & 5,09 & 1,37 & 6,54 \\
\hline
\end{tabular}

Kết quả ở bảng 4 và bảng 5 cho thấy quá trình sinh trưởng và lên men cồn của hạt đã được hoạt hóa trong hai môi trường có nguồn nitơ khác nhau là không khác nhau nhiều. Tốc độ sinh $\mathrm{CO}_{2}$ trong bình engol các mẫu đẩy cột dịch tương đương nhau. Tuy nhiên, vi sinh vật hiếu khí sử 
dụng nguồn nitơ hữu cơ dễ hơn còn một số ít loài mới có khả năng đồng hóa nitơ vô cơ nên để hạn chế sự phát triển của vi sinh vật hiếu khí trong môi trường hoạt hóa giàu chất dinh dưỡng. Như vậy, nguồn nitơ vô cơ (urê) sẽ được ưu tiên sử dụng.

Bảng 5. Ảnh hưởng của nguồn nitơ bổ sung vào dịch hoạt hóa đến tốc độ sinh $\mathrm{CO}_{2}$ trong bình engol của hạt tể bào nấm men cố định.

\begin{tabular}{|c|c|c|c|c|c|c|c|c|c|c|c|c|}
\hline \multirow{2}{*}{$\begin{array}{c}\text { Nguồn } \\
\text { nitơ }\end{array}$} & \multicolumn{10}{|c|}{ Lượng $\mathrm{CO}_{2}$ sinh ra trong bình engol $(\mathrm{ml})$} \\
\cline { 2 - 13 } & $<12 \mathrm{~h}$ & $13 \mathrm{~h}$ & $15 \mathrm{~h}$ & $17 \mathrm{~h}$ & $19 \mathrm{~h}$ & $21 \mathrm{~h}$ & $23 \mathrm{~h}$ & $25 \mathrm{~h}$ & $27 \mathrm{~h}$ & $28 \mathrm{~h}$ & $29 \mathrm{~h}$ & $30 \mathrm{~h}$ \\
\hline Urê & 0 & 0,1 & 0,1 & 0,2 & 0,3 & 0,6 & 1,1 & 1,6 & 2,2 & 2,9 & 3,4 & 3,8 \\
\hline $\begin{array}{c}\text { Cao } \\
\text { nấm } \\
\text { men }\end{array}$ & 0 & 0,1 & 0,1 & 0,1 & 0,2 & 0,5 & 0,9 & 1,4 & 1,9 & 2,6 & 3 & 3,4 \\
\hline
\end{tabular}

\section{5. Ảnh hưởng của nồng độ nitơ đến quá trình hoạt hóa hạt}

Hạt tế bào nấm men cố định được hoạt hóa trong môi trường glucose $10 \%$, nồng độ urê thay đổi $0,03 \% ; 0,05 \% ; 0,1 \% ; 0,15 \%$. Kết quả sau lên men được trình bày trong bảng 6 .

Bảng 6. Ảnh hưởng của nồng độ urê trong dịch hoạt hóa đển khả năng lên men của hạt $\mathrm{TB}$ nấm men cố định.

\begin{tabular}{|c|c|c|c|c|c|c|c|c|}
\hline \multirow{2}{*}{$\begin{array}{l}\text { Nồng độ urê } \\
(\%)\end{array}$} & \multirow{2}{*}{$\begin{array}{l}\text { Độ cồn } \\
(\% \mathrm{v} / \mathrm{v})\end{array}$} & \multirow{2}{*}{$\begin{array}{c}\mathrm{CO}_{2} \\
(\mathrm{~g} / 30 \mathrm{ml})\end{array}$} & \multirow{2}{*}{$\begin{array}{c}\text { Đường } \\
\text { sót }(\mathrm{g} / \mathrm{l})\end{array}$} & \multirow[t]{2}{*}{$\mathrm{pH}$} & \multicolumn{3}{|c|}{$\begin{array}{c}\text { Nấm men trong hạt tế } \\
\text { bào cố định } \\
\left(\mathrm{CFU} \times 10^{8} / \mathrm{g}\right)\end{array}$} & \multirow{2}{*}{$\begin{array}{l}\text { Vi sinh vật hiếu } \\
\text { khí } \\
\left(\mathrm{CFU} \times 10^{5} / \mathrm{ml}\right)\end{array}$} \\
\hline & & & & & $\begin{array}{c}\text { Tổng } \\
\text { số }\end{array}$ & $\begin{array}{c}\mathrm{TB} \\
\text { sống }\end{array}$ & \begin{tabular}{|c}
$\begin{array}{c}\text { TB nảy } \\
\text { chồi }\end{array}$ \\
\end{tabular} & \\
\hline 0,03 & 10,5 & 2,75 & 20,65 & 4,2 & 6,90 & 5,05 & 1,30 & 1,19 \\
\hline 0,05 & 10,7 & 2,87 & 19,12 & 4,2 & 6,94 & 5,16 & 1,40 & 1,27 \\
\hline 0,10 & 10,1 & 2,68 & 21,15 & 4,2 & 6,55 & 5,01 & 1,15 & 2,76 \\
\hline 0,15 & 9,9 & 2,59 & 21,29 & 4,2 & 6,05 & 4,57 & 1,08 & 2,29 \\
\hline
\end{tabular}

Bảng 7. Ảnh hưởng của nồng độ urê đến tốc độ sinh $\mathrm{CO} 2$ trong bình engol của hạt tế bào nấm men cố định.

\begin{tabular}{|c|c|c|c|c|c|c|c|c|c|c|c|c|}
\hline \multirow{2}{*}{$\begin{array}{l}\text { Nồng độ } \\
\text { urê }(\%)\end{array}$} & \multicolumn{12}{|c|}{ Lượng $\mathrm{CO}_{2}$ sinh ra trong bình engol (ml) } \\
\hline & $<12 \mathrm{~h}$ & $13 \mathrm{~h}$ & $15 \mathrm{~h}$ & $17 \mathrm{~h}$ & $19 \mathrm{~h}$ & $21 \mathrm{~h}$ & $23 \mathrm{~h}$ & $25 \mathrm{~h}$ & $27 \mathrm{~h}$ & $28 \mathrm{~h}$ & $29 \mathrm{~h}$ & $30 \mathrm{~h}$ \\
\hline 0,05 & 0 & 0,1 & 0,2 & 0,4 & 0,7 & 1,1 & 1,4 & 1,8 & 2,1 & 2,6 & 3 & 3,4 \\
\hline 0,10 & 0 & 0,1 & 0,2 & 0,4 & 0,7 & 1 & 1,2 & 1,6 & 2 & 2,6 & 3,1 & 3,5 \\
\hline 0,15 & 0 & 0,1 & 0,2 & 0,5 & 0,8 & 1 & 1,3 & 1,7 & 2,1 & 2,5 & 3 & 3,4 \\
\hline
\end{tabular}

Kết quả ở bảng 6 và bảng 7 cho thấy nồng độ urê trong môi trường lên men có ảnh hưởng tới sự sinh trưởng và lên men cồn của nấm men trong quá trình hoạt hóa hạt. Môi trường có chứa $0,05 \%$ urê cho hạt tế bào cố định có kết quả lên men tốt nhất, độ cồn đạt $10,7 \%$ v/v, hàm lượng 
đường sót thấp, số lượng tế bào nấm men tổng số, số lượng tế bào sống và tế bào nảy chồi đều cao nhất. Vì vậy, nồng độ urê $0,05 \%$ được lựa chọn để bổ sung vào môi trường hoạt hóa hạt trong các thí nghiệm theo.

\section{6. Ảnh hưởng của nguồn photpho đến quá trình hoạt hóa hạt tế bào nấm men cố định}

Photpho là một yếu tố quan trọng trong hoạt động sống của nấm men. Nó là thành phần của acid nucleic, nucleoprotein, phospholipid, coenzyme, ATP... góp phần tạo hệ thống đệm điều chỉnh $\mathrm{pH}$ môi trường. Vì vậy, việc nghiên cứu ảnh hưởng của photpho tới quá trình hoạt hóa hạt là rất có ý nghĩa. Hai loại muối vô cơ được sử dụng trong nghiên cứu này là $\mathrm{KH}_{2} \mathrm{PO}_{4}$ và $\mathrm{K}_{2} \mathrm{HPO}_{4}$. Kết quả sau lên men được trình bày trong bảng 8 .

Bảng 8. Ảnh hưởng của nguồn photpho trong dịch hoạt hóa đến khả năng lên men của hạt tế bào nấm men cố định.

\begin{tabular}{|c|c|c|c|c|c|c|c|c|}
\hline \multirow{2}{*}{$\begin{array}{c}\text { Nguồn } \\
\text { photpho }\end{array}$} & $\begin{array}{c}\text { Độ cồn } \\
(\% \mathrm{v} / \mathrm{v})\end{array}$ & $\begin{array}{c}\mathrm{CO}_{2} \\
(\mathrm{~g} / 30 \mathrm{ml})\end{array}$ & $\begin{array}{c}\text { Đường } \\
\text { sót }(\mathrm{g} / \mathrm{l})\end{array}$ & $\mathrm{pH}$ & \multicolumn{2}{|c|}{$\begin{array}{c}\text { Nấm men trong hạt tế bào } \\
\text { cố định } \\
\left(\mathrm{CFU} \times 10^{7} / \mathrm{g}\right)\end{array}$} & \multirow{2}{*}{$\begin{array}{c}\text { Vi sinh vật hiếu } \\
\text { khí } \\
\left(\mathrm{CFU} \times 10^{5} / \mathrm{ml}\right)\end{array}$} \\
\cline { 5 - 8 } & & & $\begin{array}{c}\text { Tống } \\
\text { số }\end{array}$ & $\mathrm{TB}$ sống & $\begin{array}{c}\mathrm{TB} \text { nảy } \\
\text { chồi }\end{array}$ & \\
\hline $\mathrm{KH}_{2} \mathrm{PO}_{4}$ & 10,8 & 2,86 & 20,91 & 4,2 & 7,5 & 5,01 & 3,52 & 1,92 \\
\hline $\mathrm{K}_{2} \mathrm{HPO}_{4}$ & 10,3 & 2,72 & 21,73 & 4,2 & 6,98 & 4,86 & 3,07 & 2,54 \\
\hline
\end{tabular}

Bảng 9. Ảnh hưởng của nguồn photpho bổ sung vào dịch hoạt hóa đến tốc độ sinh CO2 trong bình engol của hạt tế bào nấm men cố định.

\begin{tabular}{|l|c|c|c|c|c|c|c|c|c|c|c|c|}
\hline \multirow{2}{*}{$\begin{array}{l}\text { Nguồn } \\
\text { photpho }\end{array}$} & \multicolumn{10}{|c|}{ Lương $\mathrm{CO}_{2}$ sinh ra trong bình engol $(\mathrm{ml})$} \\
\cline { 2 - 14 } & $<12 \mathrm{~h}$ & $13 \mathrm{~h}$ & $15 \mathrm{~h}$ & $17 \mathrm{~h}$ & $19 \mathrm{~h}$ & $21 \mathrm{~h}$ & $23 \mathrm{~h}$ & $25 \mathrm{~h}$ & $27 \mathrm{~h}$ & $28 \mathrm{~h}$ & $29 \mathrm{~h}$ & $30 \mathrm{~h}$ \\
\hline $\mathrm{KH}_{2} \mathrm{PO}_{4}$ & 0 & 0,1 & 0,2 & 0,3 & 0,5 & 0,8 & 1,1 & 1,7 & 2,1 & 2,6 & 3,0 & 3,4 \\
\hline $\mathrm{K}_{2} \mathrm{HPO}_{4}$ & 0 & 0,1 & 0,1 & 0,2 & 0,4 & 0,7 & 1,1 & 1,4 & 1,9 & 2,7 & 3,1 & 3,4 \\
\hline
\end{tabular}

Kết quả ở bảng 8 và bảng 9 cho thấy nguồn phốt phát cung cấp từ $\mathrm{KH}_{2} \mathrm{PO}_{4}$ cho kết quả lên men đạt độ cồn $10,8 \% \mathrm{v} / \mathrm{v}$, hàm lượng đường sót thấp hơn và số lượng tế bào nấm men tổng số, số lượng tế bào sống, tế bào nảy chồi đều cao hơn. Điều này có thể giải thích là do trong môi trường $\mathrm{KH}_{2} \mathrm{PO}_{4}$ phân ly thành ion $\mathrm{H}^{+}$làm cho hệ đệm có tính axit, ngước lại khi bổ sung $\mathrm{K}_{2} \mathrm{HPO}_{4}$ trong môi trường $\mathrm{K}_{2} \mathrm{HPO}_{4}$ sẽ phân li thành $\mathrm{OH}^{-}$làm cho $\mathrm{pH}$ môi trường có tính kiềm, trong khi $\mathrm{pH}$ thích hợp cho nấm men phát triển là $\mathrm{pH}$ hơi axit (từ 4,2 đến 5,2). Vì vậy, $\mathrm{KH}_{2} \mathrm{PO}_{4}$ được lựa chọn để bổ sung vào môi trường hoạt hóa hạt trong các thí nghiệm tiếp theo.

\section{7. Ảnh hưởng của nồng độ $\mathrm{KH}_{2} \mathrm{PO}_{4}$ đến quá trình hoạt hóa hạt}

Sau khi đã lựa chọn được $\mathrm{KH}_{2} \mathrm{PO}_{4}$ là nguồn bổ sung photphat cho quá trình sinh trưởng của nấm men, tiến hành nghiên cứu lựa chọn nồng độ tối ưu của $\mathrm{KH}_{2} \mathrm{PO}_{4}$ theo các độ khác nhau: $0,025 \% ; 0,05 \% ; 0,1 \% ; 0,15 \%$ sau đó theo dõi quá trình lên men của nấm men. Kết quả sau lên men được trình bày trong bảng 10 . 
Bảng 10. Ảnh hưởng của nồng độ $\mathrm{KH}_{2} \mathrm{PO}_{4}$ đến khả năng lên men của nấm men trong giá thể.

\begin{tabular}{|c|c|c|c|c|c|c|c|c|}
\hline \multirow{2}{*}{$\begin{array}{c}\text { Nồng độ } \\
\mathrm{KH}_{2} \mathrm{PO}_{4}(\%)\end{array}$} & \multirow{2}{*}{$\begin{array}{l}\text { Độ cồn } \\
(\% \mathrm{v} / \mathrm{v})\end{array}$} & \multirow{2}{*}{$\begin{array}{c}\mathrm{CO}_{2} \\
(\mathrm{~g} / 30 \mathrm{ml})\end{array}$} & \multirow{2}{*}{$\begin{array}{c}\text { Đường } \\
\text { sót }(\mathrm{g} / \mathrm{l})\end{array}$} & \multirow[t]{2}{*}{$\mathrm{pH}$} & \multicolumn{3}{|c|}{$\begin{array}{c}\text { Nấm men trong hạt tế bào } \\
\text { cố định } \\
\left(\mathrm{CFU} \times 10^{7} / \mathrm{g}\right)\end{array}$} & \multirow{2}{*}{$\begin{array}{c}\text { Vi sinh vật } \\
\text { hiếu khí } \\
\left(\mathrm{CFU} \times 10^{5} / \mathrm{ml}\right)\end{array}$} \\
\hline & & & & & $\begin{array}{c}\text { Tổng } \\
\text { số }\end{array}$ & $\begin{array}{c}\mathrm{TB} \\
\text { sống }\end{array}$ & $\begin{array}{c}\text { TB nảy } \\
\text { chồi }\end{array}$ & \\
\hline 0,025 & 10,2 & 2,67 & 21,98 & 4,2 & 7,05 & 4,95 & 1,87 & 1,93 \\
\hline 0,05 & 10,8 & 2,79 & 21,95 & 4,2 & 7,95 & 5,05 & 2,10 & 1,90 \\
\hline 0,1 & 10,3 & 2,67 & 22,08 & 4,2 & 7,83 & 5,15 & 1,65 & 1,84 \\
\hline 0,15 & 9,9 & 2,59 & 22,67 & 4,2 & 7,81 & 5,03 & 1,79 & 1,91 \\
\hline
\end{tabular}

Kết quả ở bảng 10 cho thấy nồng độ photpho có ảnh hưởng tới sự sinh trưởng của nấm men trong quá trình hoạt hóa hạt. Nồng độ $\mathrm{KH}_{2} \mathrm{PO}_{4} 0,05 \%$ cho kết quả lên men cồn tốt nhất. Hàm lượng cồn trong môi trường lên men đạt $10,8 \% \mathrm{v} / \mathrm{v}$, hàm lượng đường sót thấp, tổng số tế bào nấm men, số lượng tế bào sống, tế bào nảy chồi đều cao hơn các mẫu còn lại. Vì vậy, $\mathrm{KH}_{2} \mathrm{PO}_{4}$ nồng độ $0,05 \%$ được lựa chọn để bổ sung vào môi trường hoạt hóa hạt.

\section{KẾT LUẬn}

Kết quả cho thấy để tái sử dụng hạt thì thời điểm hoạt hóa để kéo dài hoạt lực của tế bào cố định là 40 ngày, dung dịch rửa hạt là dung dịch $\mathrm{NaHCO} 30,5 \%$, dùng phương pháp hoạt hóa hạt đã qua sử dụng bằng phương pháp nuôi cấy lắc 200 vòng/phút ở $30{ }^{\circ} \mathrm{C}$ trong thời gian 24 giờ. Đã chọn được một số cơ chất thích hợp để nâng cao khả năng sống và duy trì hoạt tính lên men của tế bào cố định: glucose $100 \mathrm{~g} / \mathrm{l}$, nguồn nitơ vô cơ: được sử dùng là urê và nồng độ urê: $0,05 \% ; \mathrm{KH}_{2} \mathrm{PO}_{4}$ được lựa chọn để bổ sung vào môi trường hoạt hóa hạt và nồng độ $\mathrm{KH}_{2} \mathrm{PO}_{4}$ là $0,05 \%$. Độ cồn đạt được là $10,8 \%$ v/v.

\section{TÀI LIỆU THAM KHẢO}

1. Lương Đức Phẩm - Nấm men công nghiệp, NXB Khoa học và Kỹ thuật, Hà Nội, 2009.

2. Goksungur Y., Zorlu N. - Production of ethanol from beet molasses by Ca-Alginat immobilized yeast cells in a packed-bed bioreactor, Turk Journal of Biotechnology 25 (2001) 265-275.

3. Nagashima M., Azuma M., Noguchi S., Inuzuka K. - Continuous ethanol fermentation using immobilized yeast cell, Biotechnology and Bioengineering 26 (1984) 992-997.

4. Yu J., Zhang X., Tan T. - An novel immobilization method of Sacchromyces cerevisiae to sorghum bagasses for ethanol production, Journal of Biotechnology 129 (2007) 415-420.

5. Jianliang $\mathrm{Yu}, \mathrm{Xu}$ Zhang, Tianwei Tan - An novel immobilization method of Sacchromyces cerevisiae to sorghum bagasses for ethanol production, Journal of Biotechnology 129 (2000) 415-420.

6. Lê Thanh Mai và các cộng sự - Các phương pháp phân tích ngành công nghệ lên men, Nhà xuất bản Khoa học và Kỹ thuật, Hà Nội, 2005. 


\section{ABSTRACT \\ STUDY ON ACTIVATION OF IMMOBILIZED YEAST CELLS AFTER CATALYST TIME IN ALCOHOL FERMENTATION \\ Nguyen Thi Huong ${ }^{1,{ }^{*}}$, Hoang Dinh $\mathrm{Hoa}^{2}$, Dang Hong $\mathrm{Anh}^{2}$ \\ ${ }^{1}$ Hanoi University of Science and Tecnology, 1 Dai Co Viet str., Hai Ba Trung., Hanoi, Vietnam \\ ${ }^{2}$ Food Industries Research Institute, 301 Nguyen Trai str., Thanh Xuan., Hanoi, Vietnam \\ "Email: huong.nguyenthi1@ @ust.edu.vn}

This paper is aimed to study on the activation of immobilized yeast cells after catalyst time.

After a defined time of alcol fermentation S.cerevisiae, which immobilized on Ca-Alginate decreased its activity.

To recover the quantity of yeast as well as its quality the solutions were as followings:

- Gel washing after 40 days of fermentation.

- Seed cleaning solution was $\mathrm{NaHCO}_{3} 0,5 \%$.

- Shaking at $200 \mathrm{r} / \mathrm{min}$ at $30^{\circ} \mathrm{C}$ for 24 hours.

- Luorganic nitrogen and phosphorous sources used were urea of $0,05 \%$ and $\mathrm{KH}_{2} \mathrm{PO}_{4}$ of $0,05 \%$, respechvely.

- The alcol concentration obtained after immobilization of yeast can be reache for $10,7 \%$.

Keywords: alcohol, continuous fermentation, immobilized cell, molasses. 
